\title{
International Affairs and the Public Sphere
}

\section{Citation}

Walt, Stephen. 2011. International Affairs and the Public Sphere. HKS Faculty Research Working Paper Series RWP11-030, John F. Kennedy School of Government, Harvard University.

\section{Published Version}

http://web.hks.harvard.edu/publications/workingpapers/citation.aspx?Publd=7924

\section{Permanent link}

http://nrs.harvard.edu/urn-3:HUL.InstRepos:5116457

\section{Terms of Use}

This article was downloaded from Harvard University's DASH repository, and is made available under the terms and conditions applicable to Other Posted Material, as set forth at http:// nrs.harvard.edu/urn-3:HUL.InstRepos:dash.current.terms-of-use\#LAA

\section{Share Your Story}

The Harvard community has made this article openly available.

Please share how this access benefits you. Submit a story.

\section{Accessibility}




\section{International Affairs and the Public Sphere Faculty Research Working Paper Series}

\section{Stephen M. Walt}

Harvard Kennedy School

\section{August 2011 RWP11-030}

The views expressed in the HKS Faculty Research Working Paper Series are those of the author(s) and do not necessarily reflect those of the John F. Kennedy School of Government or of Harvard University. Faculty Research Working Papers have not undergone formal review and approval. Such papers are included in this series to elicit feedback and to encourage debate on important public policy challenges. Copyright belongs to the author(s). Papers may be downloaded for personal use only. 


\section{International Affairs and the Public Sphere}

Stephen M. Walt, Harvard University

Most social scientists would like to believe that their profession contributes to solving pressing global problems. Indeed, the United States and many other modern societies subsidize university-based research and teaching on the assumption that scholars will develop useful knowledge about today's world, communicate that knowledge to their students and to the broader public, and, where appropriate, offer rigorous, well-informed advice to interested policymakers.

There is today no shortage of global problems that social scientists should study in depth: ethnic and religious conflict within and between states, the challenge of economic development, terrorism, the management of a fragile world economy, climate change and other forms of environmental degradation, the origins and impact of great power rivalries, the spread of weapons of mass destruction, just to mention a few. In this complex and contentious world, one might think that academic expertise about global affairs would be a highly valued commodity. Scholars would strive to produce useful knowledge, students would flock to courses that helped them understand the world in which they will live and work, and policymakers and the broader public would be eager to hear what academic experts had to say.

One might also expect scholars of international relations to play a prominent role in public debates about foreign policy, along with government officials, business interests, representatives of special interest groups, and other concerned citizens. Social scientists are far from omniscient, but the rigor of the scientific process and the core values of academia should give universitybased scholars an especially valuable role within the broader public discourse on world affairs. At its best, academic scholarship privileges creativity, validity, accuracy, and rigor and places little explicit value on political expediency. The norms and procedures of the academic profession make it less likely that scholarly work will be tailored to fit pre-conceived political agendas. When this does occur, the self-correcting nature of academic research makes it more likely that politically motivated biases or other sources of error will be exposed. Although we know that scholarly communities do not always live up to this ideal picture, the existence of these basic norms gives the academic world some important advantages over think tanks, media pundits, and other knowledge-producing institutions.

Yet the precise role that academic scholars of international affairs should play is not easy to specify. Indeed, there appear to be two conflicting ways of thinking about this matter.

On the one hand, there is a widespread sense that academic research on global affairs is of declining practical value, either as a guide to policymakers or as part of broader public discourse about world affairs. Former policymakers complain that academic writing is "either irrelevant or

This essay was originally posted on Thursday, July 21st, 2011 in the Academia \& the Public Sphere Essay Series, Social Science Research Council: http://publicsphere.ssrc.org/walt-international-affairs-andthe-public-sphere/ 
inaccessible to policy-makers. . locked within the circle of esoteric scholarly discussion." This tendency helps explain Alexander George's recollection that policymakers' eyes "would glaze as soon as I used the word theory." [1] As Lawrence Mead noted in 2010: "Today's political scientists often address very narrow questions and they are often preoccupied with method and past literature. Scholars are focusing more on themselves, less on the real world... Research questions are getting smaller and data-gathering is contracting. Inquiry is becoming obscurantist and ingrown.'[2]

Within the field of international affairs, this trend has led to repeated calls to "bridge the gap" between the ivory tower and the policy community.[3] Consistent with that aim, a number of prominent scholars have recently organized workshops or research projects seeking to challenge this "cult of irrelevance" and deprogram its adherents, although it is not clear whether these efforts will succeed in reversing the current drift.[4] This online symposium reflects a similar concern: how can the academic world contribute to a healthy public conversation about our collective fate, one that leads to more effective or just solutions to contemporary problems and helps humankind avoid major policy disasters?

On the other hand, closer engagement with the policy world and more explicit efforts at public outreach are not without their own pitfalls. Scholars who enter government service or participate in policy debates may believe that they are "speaking truth to power," but they run the risk of being corrupted or co-opted in subtle and not-so-subtle ways by the same individuals and institutions that they initially hoped to sway. Powerful interests are all-too-willing to use the prestige associated with academic scholars to advance particular policy goals, and scholars are hardly immune to temptations that may cloud their judgment or compromise their objectivity. Furthermore, scholars who embrace the role of a "public intellectual" may be tempted to sensationalize their findings to attract a larger audience or find themselves opining on topics on which they have no particular expertise. Instead of improving the quality of public discourse, such behavior may actually degrade it.

The remainder of this essay explores these themes in greater detail. I begin by discussing the unique contributions that academic scholars could make to public discourse on world affairs - at least in theory - highlighting their capacity to serve as an authoritative source of knowledge about the world and as an independent voice in debates about contemporary issues ( $\rightarrow$ Why Is Academic Scholarship Valuable?). I then consider why there is a growing gap between university-based scholars and both the policy world and the public sphere, and suggest that this trend is due largely to the professionalization of academic disciplines and the concomitant rise of a quasi-academic community of think tanks with explicit political agendas $(\rightarrow \underline{\text { Why Is There a }}$ Gap between Academia and the Public Sphere?). Next, I identify some of the pitfalls that scholars face when they become more active participants in the public sphere $(\rightarrow$ The Pitfalls of Engagement). I conclude by proposing several reforms that could help the social sciences make a more vital contribution to public understanding and policy formation in the broad domain of global affairs ( $\rightarrow$ What Is To Be Done?). 


\section{Why Is Academic Scholarship Valuable?}

Academics can make at least three distinct contributions to public discourse on global affairs. First, although the digital revolution has made a wealth of information from around the world accessible on a near real-time basis, most of us still lack both extensive direct data on events in far-flung areas and the background knowledge necessary to understand what new developments mean. If our town's school district is troubled or the local economy is suffering, we can observe that for ourselves and make reasonably well-informed judgments about what might be done about it. But if the issue is the war in Afghanistan, an uprising in Yemen, a naval confrontation in the South China Sea or the prospects that some battered economy will be bailed out successfully, most of us will lack the factual knowledge or conceptual understanding to know what is really going on. Even when basic information is readily available, it may be hard for most of us to put it in the appropriate context or make sense of what it means.

When citizens and leaders seek to grasp the dizzying complexity of modern world politics, therefore, they must inevitably rely upon the knowledge and insights of specialists in military affairs, global trade and finance, diplomatic/international historians, area experts, and many others. And that means relying at least in part on academic scholars who have devoted their careers to mastering various aspects of world affairs and whose professional stature has been established through the usual procedures of academic evaluation (e.g., peer review, confidential assessments by senior scholars, the give-and-take of scholarly debate, etc.).

Second, and more importantly, an independent academic community is an essential counterweight to official efforts to shape public understanding of key foreign policy issues. Governments enjoy enormous information asymmetries in many areas of political life, but these advantages are especially pronounced when dealing with international affairs.[5] Much of what we know about the outside world is ultimately derived from government sources (especially when dealing with national security affairs), and public officials often go to considerable lengths to shape how that information is reported to the public. Not only do governments collect vast amounts of information about the outside world, but they routinely use secrecy laws to control public access to this information. Government officials can shape public beliefs by leaking information strategically, or by co-opting sympathetic journalists whose professional success depends in part on maintaining access to key officials. [6] Given these information asymmetries and their obvious interest in retaining public support for their preferred policies, it is hardly surprising that both democratic and non-democratic leaders use their privileged access to information to build support for specific policies, at times by telling outright lies to their own citizens.[7]

This situation creates few problems when the policies being sold make good strategic sense, but the results can be disastrous when they don't. In such cases, alternative voices are needed to challenge conventional wisdoms and official rationales, and to suggest different solutions to the problem(s) at hand. Because scholars are protected by tenure and cherish the principle of academic freedom, and because they are not directly dependent on government support for their livelihoods, they are uniquely positioned to challenge prevailing narratives and policy rationales and to bring their knowledge and training to bear on vital policy issues. If we believe that unfettered debate helps expose errors and correct missteps, thereby fostering more effective 
public policies, then a sophisticated, diverse and engaged scholarly community is essential to a healthy polity.

Third, the scholarly world also offers a potentially valuable model of constructive political disagreement. Political discourse in many countries (and especially the United States) has become increasingly personal and ad hominem, with little attention paid to facts and logic; a trend reinforced by an increasingly competitive and loosely regulated media environment. Within academia, by contrast, even intense disputes are supposed to be conducted in accordance with established canons of logic and evidence. Ad hominem attacks and other forms of character assassination have no place in scholarly discourse and are more likely to discredit those who employ them than those who are attacked. By bringing the norms of academic discourse into the public sphere, academic scholars could help restore some of the civility that has been lost in recent years.

For all of these reasons, it is highly desirable for university-based scholars to play a significant role in public discourse about key real-world issues and to engage directly with policymakers where appropriate. As I have argued elsewhere, academic research can provide policymakers with relevant factual knowledge, provide typologies and frameworks that help policymakers and citizens make sense of emerging trends, and create and test theories that leaders can use to choose among different policy instruments. Academic theories can also be useful when they help policymakers anticipate events, when they identify recurring tendencies or obstacles to success, and when they facilitate the formulation of policy alternatives and the identification of benchmarks that can guide policy evaluation. Because academic scholars are free from daily responsibility for managing public affairs, they are in an ideal position to develop new concepts and theories to help us understand a complex and changing world.[8]

The picture sketched here is obviously something of an ideal type, and I am not suggesting that that the academic world consistently lives up to these expectations. As noted above, universitybased scholars of international affairs - and especially the disciplines of political science and history - have increasingly focused on narrow and arcane topics and are contributing less and less to policy formation or public discourse.[9] And when academics do address topics of obvious policy relevance or public interest, the results are often presented in impenetrable, jargon-ridden prose and disseminated in venues that neither policymakers nor the public are likely to read. Even when scholars have something useful to say, in short, their tendency to "speaking in tongues" diminishes their impact on the public sphere.

\section{Why Is There a Gap between Academia and the Public Sphere?}

To some degree, the gap between the ivory tower and the world of policy arises because the two spheres have different agendas and operate under different incentives and constraints. Academics focus on developing generalizations and testing conjectures as rigorously as possible, while policymakers and the public are often preoccupied with individual cases (i.e., whatever is in the headlines or in a policymaker's in-tray). Thus, scholars are delighted whenever they identify a powerful general tendency, but policymakers may be more interested in figuring out how to overcome that general tendency or worried that the case at hand might be an exception to it. Academics strive to make their work as accurate as possible, even if this takes more time, but policymakers cannot always wait until a complete analysis is possible.[10] To take a recent 
example, policymakers in the Obama administration had to respond to the 2011 "Arab Spring" long before anyone fully understood what was driving these events or where they might lead. Given these different agendas, it is not surprising that policymakers often find academic scholarship to be of less value than the scholars who produce it might wish.

Yet the growing gap between theory and practice and the declining role of scholars in the public sphere also reflects the professionalization of academic disciplines and the norms and incentives that prevail in the scholarly world. In particular, the academic disciplines that are most concerned with global affairs (political science/international relations, history, economics, sociology, anthropology/area studies, etc.) are largely governed by university-based scholars who have little if any experience in the policy world. With rare exceptions, policymakers, policy analysts, or public intellectuals do not play significant roles in the governance of academic disciplines, leaving the latter free to set their own norms and criteria of merit. Not surprisingly, scholarly disciplines have come to privilege highly specialized research (as opposed to teaching, public service, or public engagement) because that is what most members of these fields prefer to do.

Yet this was not always the case. In the distant past, thinkers such as Machiavelli, Locke, Hobbes, Madison, Marx or Burke were engaged in and inspired by the political events of their day and their writings were explicitly intended to shape public attitudes and inform elite conduct. During the Progressive Era, the founders of modern political science in the United States consciously intended the knowledge they generated to improve the world, and the creation of organizations like the American Political Science Association was intended in part to enhance the public role of political science knowledge. Not so long ago, it was not uncommon for leading scholars of global affairs to work in policy-making circles before returning to active intellectual careers or to write for both academic audiences and the broader public.[11]

By contrast, the norms and incentives of contemporary academic life discourage scholars from active participation in the public sphere or from doing work that is directly relevant to pressing global issues and accessible to influential decision-makers.[12] In the vast majority of cases, promotion to tenure and eligibility for lucrative "outside offers" from competitor universities depends on a scholar's reputation among his or her professional peers, and not on their public profile or their contributions to real-world debates. As a result, most scholars of global affairs do not try to write books or articles that would be directly relevant to policy problems or accessible to a wider public audience. Although a few "in-and-outers" still exist, they are for the most part not drawn from the very top of the disciplinary hierarchy.[13] Younger scholars are cautioned not to "waste" their time publishing op-eds, weblogs, or articles in general readership journals. Scholars who write for Foreign Policy, Foreign Affairs, or even rigorously peer-reviewed journals such as International Security are sometimes dismissed as insufficiently rigorous, based on arbitrary and dubious notions of what constitutes "genuine" scholarship."[14]

Professionalization also encourages scholars to employ specialized jargon and arcane methodological techniques, because these devices reinforce the idea that members of the discipline are privy to specialized knowledge that non-members lack. At worst, a trivial result that relies on the latest methodological fad will be judged superior to a bolder, more counterintuitive, or potentially more fruitful argument that is presented in clear and easy-tounderstand prose. More advanced methods or techniques are preferable when they yield superior 
results, of course, but methodological sophistication alone tells us relatively little about the value or the insights embodied in a particular work.

In fact, there is no great mystery as to what makes a piece of scholarship valuable. First, does it address an important question? Second, does it offer a creative or original answer, one that substantially alters our prior understanding of the phenomenon under study? Third, are its empirical claims valid and convincing? Finally, is it presented as clearly and accessibly as possible, so that it can reach the largest possible audience (including the largest number of potential critics)?[15] Each of these qualities is important, and privileging methodological sophistication over the others is a hallmark of a "professionalized" discipline that, as a consequence, maximizes its autonomy, insulates itself from public scrutiny, and reinforces the belief that its members possess specialized knowledge that is available only to them. At the most extreme, hyper-professionalized disciplines are like a guild of silversmiths whose members are judged solely on the purity of the metal in their objects, and not on whether the items they made were useful, durable, or attractive. A similarly one-dimensional approach to scholarship inevitably widens the gap between the ivory tower, the policy world, and the public sphere.

Professionalization also discourages academic scholars from addressing controversial topics or challenging well-established taboos. Although university scholars are quick to defend the institution of tenure and the principle of academic freedom, in most cases this commitment has more to do with a desire for lifetime sinecures than a commitment to using these protections to take on politically controversial topics. Smart young scholars know that being too controversial can annoy potential donors, alarm deans and department chairs, and alienate senior colleagues, thereby undermining prospects for promotion or later advancement. Focusing one's efforts on narrow and uncontroversial topics that are of interest only to one's fellow academicians is by far the safer route to the Holy Grail of lifetime employment. Given this incentive structure, it is hardly surprising that academic engagement in the public sphere and the policy world is declining.

Last but not least, the "cult of irrelevance" in academe is probably related to the concomitant emergence of independent think tanks. Although such organizations increasingly mimic the academic world (e.g., by appointing fellows to "endowed chairs" to convey a quasi-academic image and aid fund-raising efforts), the two realms are quite different. Not only do most think tanks exist in order to advance an explicit political agenda, but researchers at these organizations are often dependent on "soft money" and do not enjoy the full protections of tenure. They have become increasingly influential in recent years in part because of their proximity to centers of power like Washington, New York, and London, but also because they work much harder than universities do at wielding influence in the policy world. And although think tanks like the RAND Corporation and the Brookings Institution once performed research that was as rigorous and influential as most academic scholarship, this is no longer the case. To the extent that think tanks also provide sinecures for once-and-future policymakers when their party is out of power, then these organizations will be even less likely to produce research or commentary that challenges the prevailing "Establishment" consensus. 


\section{The Pitfalls of Engagement}

Yet a more intimate connection between scholars, policymakers, and the broader public carries its own pitfalls as well. For starters, academics aspiring to hold government positions may be even less likely to tackle controversial topics or take unpopular positions, because doing so might jeopardize their chances for a future appointment. Indeed, because political appointees are chosen primarily for their loyalty and ideological compatibility and not for scholarly accomplishment, academics who seek direct policy jobs are bound to tailor their work to suit those who might appoint them (or in the United States, to appease the Senators who will vote to confirm their appointments). This tendency does not mean that scholars will say things they don't believe merely to get a job in government, but it would be naïve to think that this concern never influences what an ambitious scholar would be willing to say in public.

Greater engagement can lead to other conflicts of interest as well. In particular, academics working on important aspects of global affairs may enjoy lucrative opportunities to do outside consulting, often at the behest of wealthy or well-funded interests. National security experts are sometimes hired to consult for the Department of Defense or a major defense contractor, for example, or an economist might consult for banks, hedge funds or private corporations. Different government agencies also hire consultants and sponsor academic research projects, which may tempt recipients to tailor their work to fit the agency's preferences or to refrain from publishing results that might be embarrassing to the funder.[16]

If relationships like these are not publicly disclosed, it is hard to know whether a scholar's views on a given issue reflects a genuine scholarly conclusion or whether it is at least partly influenced by financial or other professional incentives. At the very least, consumers of a scholar's work should be informed about these arrangements so that they can take obvious conflicts of interest into account.

Even when money is not at issue, closer engagement with the real world creates other sources of potential bias. Scholars are only human, after all, and they are hardly immune from seduction by powerful interests or individuals. Being asked to advise the Secretary of State, to participate in a Defense Department junket to Afghanistan or Iraq, or to serve on a government task force can be a heady experience, and scholars may also regard such service as a patriotic duty. But academics that enjoy hobnobbing with public officials or powerful private interests may become reluctant to do or say anything that might jeopardize their insider status. Instead of "speaking truth to power," in short, academics can easily slide into telling the powerful what they want to hear, or at least confining their comments to what they think is the "acceptable" range of opinion.

There is even a potential downside when academics become "public intellectuals." On the one hand, scholarly engagement in the public sphere increases public awareness of key issues and foster a more informed and responsible citizenry. There may also be a link between public engagement and more effective teaching: the same skills that help academics explain complex ideas to untrained students can make them more effective at informing the public (and vice versa). Writing op-eds, blogs, popular books, and articles is also a way to fulfill academia's broader responsibility to help society address important public problems, instead of engaging mostly in a self-serving internal dialogue among specialists. 
The danger, however, is that a craving for public attention (not to mention book sales, speakers' fees, and other rewards) will encourage some scholars to cast off academic rigor entirely and court notoriety for notoriety's sake. It can also encourage scholars to opine on topics that are far from our established areas of expertise and where we have no special insight or wisdom to impart.

While there is an obvious problem with the "cult of irrelevance," in short, there is also a danger that academic scholars can become little more than hired guns; handmaidens to powerful interests instead of pursuers and proclaimers of truth. And if that happens, then academia's unique ability to serve as an independent and critical source of authoritative knowledge will be impaired. In short, no matter how much we may want academics to be more fully engaged in the public sphere, we should also acknowledge that it is hard to have the best of both worlds.[17]

\section{What Is To Be Done?}

As scholars, therefore, our challenge is to chart a course between the Scylla of hyperprofessionalized irrelevance and the Charybdis of corrupt opportunism. We should begin by recognizing that the norms and incentives that guide the scholarly enterprise are neither divinely ordained nor fixed in stone; like all norms, they are "socially constructed" by the academic community itself and by the outside stakeholders who have an interest in what the academy produces. Members of academic disciplines are free to debate and determine which norms and incentives should guide our enterprise and to modify them as experience suggests. There is no objective reason why greater engagement in the public sphere cannot be elevated in our collective estimation, along with the other criteria (rigor, originality, empirical validity, etc.) that scholars have traditionally (and correctly) prized.

If consensus on these norms proves elusive, then different universities or departments could adopt different criteria of merit and evolve in different directions. To some extent this may already be occurring, as schools of public policy begin to occupy the policy-relevant space abandoned by hyper-professionalized arts and sciences departments. Indeed, greater disagreement about the norms used to judge academic work might even be desirable, because a heterogeneous intellectual community working on these issues is probably preferable to a monoculture where a single method, theoretical perspective or political orientation predominates.[18] Even the best social science theories are highly imperfect, and once-popular ideas and approaches are often exposed as hollow with the passage of time. When dealing with vital yet contentious issues (i.e., the sorts of topics that routinely arise in world affairs), we will be better off nurturing a diverse intellectual ecosystem instead of placing all our bets on a single way of trying to grasp something as complex and contingent as international affairs.

The bottom line is clear: the academic study of international affairs will be impoverished if the relevant academic disciplines continue to turn inward, to focus on narrow issues that are primarily of interest only to other scholars, and to become even less interested in communicating to policymakers, the broader public, or the bulk of our students (the vast majority of whom do not want to be social scientists themselves). Accordingly, our goal should be to encourage a diverse, engaged community of scholars that is still committed to a free exchange of ideas and to high standards of both rigor and relevance. 
What can be done to advance this goal? Here are six steps that would encourage greater academic engagement in the public sphere without sacrificing a commitment to high scholarly standards.

\section{Give Greater Weight to Real World Impact when Evaluating Individual Scholars and Academic Departments}

First, and most obviously, academic departments could give greater weight to policy relevance and public impact in hiring and promotion decisions. Instead of focusing almost entirely on peerreviewed professional journals and/or monographs by university presses, for example, promotion review committees could also do a systematic evaluation of a candidate's other contributions to knowledge and public discourse, including weblogs, popular journals, trade books, or other professional studies (such as National Academy of Science proceedings). As Bruce Jentleson noted a decade ago, "Should it really be the case that a book with a major university press and an article or two in a [refereed] journal . . . can almost seal the deal for tenure, but books with even major commercial houses count so much less and articles in journals such as Foreign Affairs count little if at all? ... The argument is not about padding publication counts with op-eds and other such commentaries, but it is to broaden evaluative criteria to better reflect the type and range of writing of intellectual import."[19] Jentleson is surely right; it is the substance of a scholar's work that should count, not where it happens to have been published.

This shift might be facilitated by another innovation, which was recently discussed among participants in the "Perestroika" movement in political science. What if junior faculty were told at the time they were hired that they would be permitted to submit no more than five scholarly works when being considered for promotion to tenure? Instead of encouraging younger scholars to churn out as many publications as possible (most of which will not even be read by most of the colleagues who will eventually vote on their case), this procedure would encourage scholars to publish fewer works of higher quality and to aim for greater overall impact. As Lenin put it in another context, "better fewer, but better." This norm would also make it easier for outside referees and senior colleagues to read these works in depth and to judge them on their merits, instead of using the alleged prestige of the the journal or press as a proxy for a publication's intellectual merit.

Similarly, instead of focusing primarily on sheer quantity of academic publications or imperfect measures like citation counts, review committees could be asked to perform a more systematic evaluation of a scholar's impact on public discourse or policy debate.[20] In addition to academic citation counts, for example, a review committee could also track the number of news reports or blog hits that discussed a candidate's work, or examine citations in both academic and non-academic journals. Similarly, in addition to obtaining the usual outside letters from senior scholars, review committees could also solicit evaluations from policymakers working in the same domain as the candidate's primary work. Non-academic appraisals must be used with caution, of course, as outsiders may be unfamiliar with academic standards or inclined to favor only those works that agreed with their political views. And they are certainly no substitute for the confidential appraisals offered by senior scholars. But if an academic department cared about having a faculty that made positive contributions to the broader public sphere, then surely it would want to know if a junior scholar working on a topic like ethnic conflict or nuclear 
proliferation was being read by important members of the relevant policy community or if their work was helping shape how people outside academia thought and talked about these issues.

A similar principle could also be applied to the evaluation of entire departments. External review committees should contain obviously scholars from the relevant discipline, but they could include people drawn from outside academia as well. Instead of focusing on the deeply-flawed rankings provided by U.S. News and World Report or the National Research Council, new efforts could be made to devise evaluative methodologies that were not stacked in favor of certain types of work.[21] Ranking indexes could also measure and incorporate on a department's contributions outside the academy. University presidents, provosts, and deans could start holding departments accountable to a broader conception of merit as well, by stressing not just narrow technical excellence but also the substantive importance of the faculty's work and the contributions it had made to public understanding of them.

\section{Encourage Professional Associations to Honor Public Impact}

Professional associations could encourage greater involvement in the public sphere by doing more to acknowledge and valorize it. Consider that the American Political Science Association gives literally dozens of annual awards for books, papers or articles in the various sub and subsub-fields of the discipline, judged almost entirely on a prize jury's assessment of scholarly merit. It gives one award (the Hubert H. Humphrey Award) "in recognition of notable public service by a political scientist," and one other award (the Charles Merriam Award) for "a person whose published work and career represent a significant contribution to the art of government." In short, real-world relevance is germane to only two of the dozens of APSA prizes awarded each year. If we want scholars to devote more time to engaging in the public sphere, reducing this imbalance by making real-world impact or relevance an explicit criterion for the existing awards would almost certainly help, as would the creation of more prizes intended to honor scholars whose work or careers are judged to have had a positive impact on the public sphere itself.

\section{Encourage Younger Scholars to Participate in Policy-Related Activities}

Academic departments could encourage greater involvement in the public sphere by making it easier for younger scholars to engage in it, either on their own or through programs like the International Affairs Fellowships sponsored by the Council on Foreign Relations.[22] At present, few academic departments encourage junior scholars to take time off for public service, and few universities will stop the tenure clock if a junior faculty member wants to spend a year serving in government or at a non-governmental organization such as Human Rights Watch, the United Nations, or the World Bank. If they enabled younger faculty to stop the clock in this way, however, academic departments would have more members who understood how governments and key global organizations actually worked, and they would become more adept at translating scholarly research into useful knowledge for their students and practical guidance for policymakers and the public at large. Such individuals would probably be better teachers as well, because students, unlike many professional academics, really do care about the real world and have little tolerance for empty scholasticism. 


\section{Engage Policymakers and Knowledgeable Citizens in the Research Process}

As Craig Calhoun suggests in his own contribution to this symposium, the scholarly world should do more to engage policymakers and other non-academic experts in the research process itself, instead of seeing them solely as objects of study. We expect today's graduate students to master an elaborate methodological toolkit and to be familiar with an ever-expanding academic literature, but we rarely encourage them to interact with the policy communities whose decisions and actions they are studying and rarely give them explicit training on how to "soak and poke" among policy elites. Not surprisingly, therefore, younger scholars are often content to manipulate data sets or to write detailed case studies, but without engaging in any depth with the policymakers working in the relevant domain.

Furthermore, if academic scholars made a practice of asking practitioners what topics or questions might be most interesting or useful, the benefits for both communities might be considerable. For instance, what if people with real-world experience were regarded not just as potential consumers of scholarship or as data points in a survey, but as a source of guidance about scholarly research agendas, methods, and modes of presentation? Instead of deriving dissertation topics or research ideas primarily from lacunae in the academic literature, we could also ask policymakers what sorts of knowledge they would most like to have, or what recurring puzzles merit extended scholarly attention. Among other things, outside experts are more likely to ask "so what?" when confronted by an elegant and well-crafted study addressing a question that is of interest to hardly anyone.

In the same spirit, we could also encourage students to plumb real-world policy debates in order to identify underlying theoretical or empirical disputes that drive policy disagreements.

Obviously, scholars should still develop their own research agendas and not take their marching orders from non-academics blindly, but more extensive dialogue between the worlds of theory and of practice at the initial stages of a research project could improve the overall quality of the research itself and make it more likely that policymakers would pay attention to the results.

\section{Convince University Administrators to Value Participation in the Public Sphere}

Presidents, provosts and deans can facilitate these adjustments by allocating greater resources to departments and programs that are producing socially useful knowledge and making more substantial contributions to the broader public sphere. To be sure, university administrators are often pleased whenever some member of their faculty gains broad attention - though somewhat less so when their work is controversial - but few of them encourage faculty or departments to raise their public profile or give them clear incentives to do so.

Another way to increase the public impact of universities, as Rogers Smith points out in his own essay in this symposium, is to place greater emphasis on the traditional role of teaching. Effective teaching is one of our responsibilities as scholars and student interest is one way to gauge whether a department's activities are broadly relevant to contemporary issues. University administrators should place greater weight on this contribution, and allocate greater resources to departments, programs and schools that perform well on this dimension. 
The reforms sketched here are not intended to transform today's academy into a community of headline-chasing policy analysts competing to win the attention of government officials, an army of spell-binding orators catering to hordes of fawning undergraduates, or a cadre of public intellectuals focused more on launching best-sellers and hitting the talk-show circuit than on conducting path-breaking original scholarship. Rather, the goal is to foster a more heterogeneous community at all levels of academe, based on the recognition that scholars can contribute to a vibrant and constructive public sphere in many different ways, including some that have little to do with publication in peer-reviewed disciplinary journals.

\section{Broaden the Discussion of Academic Ethics and Responsibilities}

Scholars who study global affairs also need to have a long-overdue discussion about the broader ethical responsibilities of our profession. To the extent that professional training in the social sciences deals with ethical issues at all, the focus is usually confined to questions of academic fraud, academic freedom, the treatment of human subjects, or potential abuses of power (such as sexual harassment). As scholars, we rarely talk about the larger purpose of our profession, the broader social role we supposedly fulfill, or how we should meet our larger obligations to the society that supports us. Whatever their other flaws may be, the legal and medical professions are clear about what their central purpose is, and they incorporate discussions of ethics and social purpose into the training of new doctors and lawyers. By contrast, social scientists rarely discuss their public responsibilities and this topic plays little or no role in graduate training in most academic departments.[23] If it did, it might raise some awkward but useful questions about whether our profession exists largely for our entertainment and livelihoods, or whether society has a right to expect something more.

A related issue is how scholars should deal with potential conflicts of interest, and especially where significant sums of money are involved. Virtually all universities permit their faculty to do some amount of outside consulting, but there is no agreed-upon standard for how scholars can preserve their integrity and their reputations as objective experts when they are also being compensated (and in some cases, quite generously) for related professional work. Nor is this just a concern for the individuals who are doing this work, because conflicts of interests, once exposed, can affect the reputation of an entire department or university and cast a shadow on the entire profession. Were the public (or key legislators) to begin seeing the social sciences as little more than hired guns, they will be even less likely to take our work seriously or to give universities the resources they need to remain vibrant and independent.

Fortunately, transparency provides a simple solution to this problem. Individual scholars should remain free to do whatever outside work they wish (subject to the regulations of their particular university), provided that they disclose such relationships publicly, including the actual level of compensation involved. For example, universities could require scholars who do outside consulting for pay to report this information on a public website, identifying sources of outside income within broad bands (e.g., \$0-999, \$1000-4999, \$5,000-9,999, \$10,000 and higher, etc.). Academics would still be free to write whatever they wished in both scholarly and non academic venues, but consumers of their various writings could decide whether to discount the conclusions or not. Such a procedure would not infringe on individual or academic freedom, but it would ensure that consumers of academic scholarship on vital topics would be aware of potential sources of bias. Such a norm might also have a valuable deterrent effect: if an individual scholar 
was tempted to accept compensation but reluctant to have the relationship made public, it is probably a revealing sign that the relationship itself is inappropriate.

\section{Conclusion}

Is this vision of a more engaged, diverse, rigorous-but-still-relevant, and fiercely independent social science a pipe dream? Perhaps, if academic departments continue to privilege narrow disciplinary orthodoxy instead of embracing a conception of scholarly merit that also includes relevance, accessibility, theoretical fertility, and public impact. If scholars working on global affairs are content with having little to say to their fellow citizens and public officials and little to contribute to solving public problems, then we can expect even less attention and fewer resources over time (and to be frank, we won't deserve either). By contrast, if the academic community decides to use its privileged position and professional expertise to address an overcrowded global agenda in a useful way, then it will have taken a large step toward fulfilling its true social purpose. Therein lies the good news: the fate of the social sciences is largely in our own hands. 


\section{FOOTNOTES}

1. See David Newsom, "Foreign Policy and Academia," Foreign Policy 101 (1995-96); and Alexander L. George, "Foreword," in Miroslav Nincic and Joseph Lepgold, eds., Being Useful: Policy Relevance and International Relations Theory (Ann Arbor: University of Michigan Press, 2000). This sense of dissatisfaction is not a new phenomenon. Nearly sixty years ago, Hans J. Morgenthau complained that "the retreat into the trivial, the formal, the methodological, the purely theoretical, the remotely historical — in short, the politically irrelevant — is the unmistakable sign of a 'non-controversial' political science that has neither friends nor enemies because it has no relevance for the great political issues in which society has a stake." See M. Benjamin Mollov, Power and Transcendance: Hans J. Morgenthau and the Jewish Experience (Lexington: Lexington Books, 2002), p. 42.^

2. Lawrence Mead, "Scholasticism in Political Science," Perspectives on Politics 8, no. 2 (June 2010). $\uparrow$

3. See, among others: Peter Feaver, "The Theory-Policy Debate in Political Science and Nuclear Proliferation," National Security Studies Quarterly 5, no. 3 (1999); Christopher Hill and Pamela Beshoff, eds., The Two Worlds of International Relations: Academics, Practitioners, and the Trade in Ideas (London: Routledge, 1994); Joseph Lepgold, "Is Anyone Listening?: International Relations Theory and Policy Relevance" Political Science Quarterly 113, no. 3 (1998); Bruce Jentleson, "The Need for Praxis: Bringing Policy Relevance Back In," International Security 26, no. 4 (2002); Joseph Nye, "Scholars on the Sidelines," Washington Post, April 13, 2009; and Stephen M. Walt, "The Relationship between Theory and Policy in International Relations," Annual Review of Political Science 8 (2005). $\uparrow$

4. Such efforts include: 1) the Tobin Project, which describes itself as "an alliance of the nation's leading academics united by a belief in the power of ideas and a shared commitment to using ideas to improve the lives of their fellow citizens"; 2) the "Bridging the Gap" workshop organized by Bruce Jentleson, Steven Weber, and James Goldgeier, and a recent workshop on the "cult of irrelevance" sponsored by the Carnegie Corporation of New York. $\uparrow$

5. See Chaim Kauffmann, "Threat Inflation and the Failure of the Marketplace of Ideas," International Security 29, no 1 (2004); and Stephen Van Evera, "Why States Believe Foolish Ideas: Non-Self-Evaluation by States and Societies." 1

6. This situation helps explain why Wikileaks founder Julian Assange has been condemned for releasing vast quantities of previously classified information, but Washington Post reporter Bob Woodward is a respected Establishment figure, even though Woodward's best-selling books contain classified information that has been leaked to him by government officials. See, for example, Obama's Wars (New York" Simon \& Schuster, 2010).^

7. See John J. Mearsheimer, Why Leaders Lie: The Truth about Lying in International Politics (New York: Oxford University Press, 2010). $\uparrow$

8. See Walt, "Relationship between Theory and Policy." $\uparrow$

9. See Nye, "Scholars on the Sidelines." $\uparrow$

10. As Harvard professor and former State Department official Robert Bowie once recalled, "the policymaker, unlike the academic analyst, can rarely wait until all the facts are in. He is very often under strong pressure to do something, to take some actions." Quoted in Ernest May, Knowing One's Enemies: Intelligence Assessment Before the Two World Wars (Princeton: Princeton University Press, 1984). $\uparrow$

11. Obvious examples include Robert Bowie, McGeorge Bundy, Walt Rostow, John Kenneth 
Galbraith, Henry Kissinger, Zbigniew Brzezinski, William Quandt, and Richard Cooper. It is also worth recalling that leading scholars like Hans J. Morgenthau published regularly in "state of the art" academic journals and in public venues such as the New York Times Magazine. $\uparrow$ 12. According to Adam Przeworski, "the entire structure of incentives in academia in the United States works against taking big intellectual and political risks. Graduate students and assistant professors learn to package their intellectual ambitions into articles publishable by a few journals and to shy away from anything that might look like a political stance. ... We have the tools and we know some things, but we do not speak about politics to people outside academia." Quoted in Gerald Munck and Richard Snyder, "What Has Comparative Politics Accomplished?" APSA-CP Newsletter 15, no. 2 (2004).^

13. Of the 25 "most influential" scholars identified in the 2010 William \& Mary survey on Theory and Research on International Politics (TRIP), only five have any significant policy experience. The five individuals were Samuel Huntington, Joseph Nye, John Ruggie, Michael Doyle, and Stephen Krasner. It is perhaps noteworthy that Huntington died in 2009, the other four are over 60 years of age, and only Doyle and Krasner served in the past decade. The survey can be found here. $\uparrow$

14. According to the Institute for Scientific Information (the main source of scholarly citation counts) the journal International Security had the highest "impact factor" (in terms of scholarly citations) of 73 international relations journals in eight separate years since 1996. It ranked $2^{\text {nd }}$ three times, $3^{\text {rd }}$ once, $4^{\text {th }}$ twice, and $5^{\text {th }}$ once. Yet there are anecdotal reports that some scholars or departments discount publication in IS by claiming (incorrectly) that is not peer-reviewed or asserting that is not "rigorous" enough. Many academics also believe scholarly publications enjoy higher status if they appear in "general interest" journals such as the American Political Science Review, instead of in sub-field journals such as World Politics, International Studies Quarterly, or International Organization. This criterion of merit makes no sense, because the real issue is the contents of a scholarly publication and not where it happened to be published. Moreover, we do not ask scholars from different subfields of a discipline to evaluate manuscripts in other areas or to write tenure letters for people who work in very different sub-fields, so it is not clear why publication in a broad "field journal" is of greater value. Assuming these reports are accurate, it suggests a subtle attempt to stack hiring or promotion proceedings in favor of certain sub-fields or styles of work, and against others. $\uparrow$

15. Accessibility also increases the number of potential critics, because the more people that can read and understand a given argument, the more potential challenges it is likely to face. Other things being equal, therefore, making scholarship as clear as possible contributes to our collective ability to evaluate its merits. $\uparrow$

16. A troubling example of this tendency was Fannie Mae's decision to fund a significant fraction of academic research on housing markets in the 1990s. According to Gretchen Morgenson and Joshua Rosner, the resulting research rarely questioned Fannie Mae's favored status or challenged the supposedly constructive role it played in the housing and mortgage market. See their Reckless Endangerment: How Outsized Ambition, Greed and Corruption Led to Economic Armageddon (New York: Times Books, 2011). In the national security field, the Pentagon's Office of Net Assessment has hired a large number of younger scholars as consultants over the years, a practice that may have also created a cadre of scholars who are indebted to ONA and inclined to support its world-view. $\uparrow$

17. For a discussion of these issues in the context of research on national security, see Michael W. Mosser, "Puzzles Versus Problems: The Alleged Disconnect between Academics and Military Practioners," Perspectives on Politics 8, no. 4 (2010), and also the various responses by 
Robert Albro, Paul Bracken, Craig Calhoun, Cynthia Enlow, Ron Krebs, and Paul Yingling. See also the preceding discussions in the SSRC essay forum The Minerva Controversy. $\uparrow$

18. Within political science, my impression is that the field is more much homogeneous than it was thirty years ago. In the 1970s, there were clear and significant differences between the major departments, most of which had distinct intellectual identity. Harvard was different from Michigan, which was clearly distinct from the University of Chicago, which was not that much like Yale or Stanford or MIT or Berkeley, etc.) Today, by contrast, faculty in most departments are more similar than they are different and $\mathrm{Ph}$.D. students receive remarkably similar disciplinary training. Distinctions do exist between different departments, of course, but the overall trend has been toward convergence. $\uparrow$

19. See Bruce Jentleson, "In Pursuit of Praxis: Applying International Relations Theory to Foreign Policymaking," in Nincic and Lepgold, Being Useful. $\uparrow$

20. At the Harvard Kennedy School where I teach, hiring and promotion decisions are based on five criteria: 1) quality of mind, 2) scholarship, 3) teaching performance, 4) contributions to applied public policy and management, and 5) citizenship. Although in practice "scholarship" tends to dominate hiring and promotion decisions for ladder faculty, the other criteria are explicitly assessed and discussed and have played important roles in the outcome of certain cases. The weights attached to each criterion are not fixed, and could therefore be adjusted to encourage greater (or lesser) involvement in the public sphere. $\uparrow$

21. The methodology used in the 2010 National Research Council ranking of graduate programs has been widely and deservedly criticized. Among its many flaws, the survey used citation counts based on peer-reviewed scholarly articles but not books, and each author of a multipleauthored article receives the same credit as a scholar who writes an article entirely on their own. This procedure favors disciplines or sub-fields where articles and co-authorship are the norm, as opposed to fields where writing books and sole-authorship is more widespread. For a critical analysis of the NRC study's methodology, see the unpublished Powerpoint presentation by Michael Desch of Notre Dame University, available from him at mdesch@,nd.edu. For additional discussion of the NRC study's flaws, see Jonathan Cole, "Too Big to Fail," Chronicle of Higher Education, April 24, 2011. $\uparrow$

22. The International Affairs Fellowship (IAF) program was originally created to provide scholars less than thirty-five years of age with the opportunity to serve in government for one year. Yet between 2000 and 2005, only 35 percent of the IAF participants were tenure-track scholars, and that percentage declined to only 20 percent for the period 2006-2011. Calculated from data at http://www.cfr.org/thinktank/fellowships/iaf.html $\uparrow$

23. Two good places to start are Larry Diamond, "What Political Science Owes the World," PS Online; and Robert Putnam, "The Public Role of Political Science," Perspectives on Politics 1, no. 2 (June 2003).^ 